\title{
HUBUNGAN KARAKTERISTIK RESPONDEN DENGAN PARTISIPASI MASYARAKAT DALAM KEGIATAN PENGELOLAAN HUTAN LINDUNG GUNUNG NONA DI KOTA AMBON PROPINSI MALUKU \\ (Relationship Between Respondents Characteristics and Community Participation in Management Activity in Gunung Nona Protected Forest in Ambon City, Moluccas Province)
}

\author{
Oleh/By : \\ Messalina L Salampessy ${ }^{1}$, Bramasto Nugroho ${ }^{2}$, Herry Purnomo ${ }^{3}$ \\ ${ }^{1}$ Dosen Universitas Pattimura, Fakultas Pertanian Jurusan Kehutanan \\ Jl. Ir .M. Putuhena Kampus Poka-Ambon, Tlp 0911-322626 Fax 0911-322626 \\ Email : meis_forester@yahoo.com \\ ${ }^{2,3}$ Dosen Institut Pertanian Bogor Fakultas Kehutanan \\ Kampus IPB Darmaga Bogor, Tlp 0251-622640 Fax 622986
}

Diterima 17 Juli 2012, disetujui 29 Agustus 2012

\begin{abstract}
Management of Protected Forest areas are often faced with dilemma between the interests of preserving forests as a buffer for various aspects of life with the interests and needs of the region. The effectiveness of the management of the area will be disturbed due to low participation and interaction that are less supportive. People living in the area around Gunung Nona Protected Forest (HLGN) still has a dependency closely with the region and their livelihood related with dusung management. Dusung is a traditional plantation of Maluku community where there are different types dominated by woody plants and trees producing fruit, in part combined with other beneficial plants and animals. The purpose of this research is to identify and measure community participation in the management of protected forest and analyze heterogeneity and characteristics of individuals and organizations that influence the level of participation in the management of the forest. The research used the frequency distribution analysis with cross-tabulations and Chi squared (Chi Square) technique. Research results indicate that the heterogeneity of factors and characteristics (individuals and organizations) who bave a close relationship and effect on community participation in park management HLGN is the knowledge of forests, size of land tenure of dusung, dusung ownership status, length of involvement in the organization and relations with officers and members in the organization.
\end{abstract}

Keywords: Participation, heterogeneous, dusung

\section{ABSTRAK}

Pengelolaan kawasan Hutan Lindung sering dihadapkan pada dilema antara kepentingan pelestarian hutan sebagai penyanggah berbagai aspek kehidupan dengan kepentingan dan kebutuhan masyarakat terhadap kawasan tersebut. Efektifitas pengelolaan kawasan tersebut akan terganggu karena rendahnya partisipasi masyarakat dan interaksinya yang kurang mendukung. Masyarakat yang tinggal di sekitar kawasan Hutan Lindung Gunung Nona (HLGN) masih memiliki ketergantungan erat dengan kawasan ini dan berhubungan dengan mata pencaharian mereka dari pengelolaan dusungnya. Dusung adalah areal kebun tradisional masyarakat Maluku, dimana terdapat berbagai jenis tanaman berkayu dan didominasi oleh jenis pohon penghasil buah-buahan, sebagian dikombinasikan dengan tanaman-tanaman bermanfaat lainnya maupun hewan ternak. Tujuan riset ini adalah untuk mengetahui dan mengukur partisipasi masyarakat dalam pengelolaan kawasan Hutan Lindung dan menganalisis heterogenitas dan karakteristik individu dan organisasi masyarakat yang mempengaruhi tingkat partisipasi dalam pengelolaan kawasan Hutan Lindung. Riset ini menggunakan analisis distribusi frekuensi dengan tabulasi silang yang kemudian diuji dengan teknik Chi kuadrat (Chi Square). Hasil riset menunjukkan bahwa faktor heterogenitas dan karakteristik (individu dan organisasi) yang mempunyai hubungan erat dan berpengaruh terhadap partisipasi masyarakat dalam pengelolaan kawasan HLGN adalah pengetahuan tentang hutan lindung, luas penguasaan lahan dusung, status pemilikan dusung, lama keterlibatan dalam organisasi serta hubungan pengurus dan anggota masyarakat dalam organisasi.

Kata kunci: Partisipasi, heterogenitas, dusung 


\section{PENDAHULUAN}

Pada beberapa kawasan hutan lindung, interaksi antar masyarakat lokal dengan sumberdaya alam masih sangat kuat. Bahkan di beberapa lokasi, pola interaksi yang terjalin memberikan kecenderungan positif terhadap kelestarian hutan (Wiratno et al, 2004). Upaya untuk berpartisipasi senantiasa diinginkan oleh masyarakat namun demikian, hingga saat ini peran partisipasi belum sepenuhnya optimal namun masih pada tahapan menginformasikan dari tahapan tangga partisipasi yang diharapkan Arnstein, 1995) dalam komite Multistakeholder Forestry Programme et al. 2006. Partisipasi masyarakat adalah suatu proses yang memberi kesempatan kepada masyarakat secara individu atau kelompok untuk mempengaruhi keputusan publik termasuk di dalamnya kesempatan berpartisipasi dalam pengelolaan hutan (Cohan dan Sharp, 1995) dalam Poteete and Ostrom, 2004.

Seperti halnya kawasan hutan lindung lainnnya, Hutan Lindung Gunung Nona (HLGN) di kota Ambon menghadapi tekanan populasi penduduk yang terus bertambah dan persoalan sosialekonomi yang harus dipenuhi dan cenderung meningkat. Permasalahan yang terjadi di HLGN maupun di tempat lain merupakan masalah kelembagaan terutama menyangkut hak penguasaan dan pengelolaan sumberdaya alam antara pemerintah dan masyarakat lokal dimana aspek partisipasi diupayakan sebagai salah satu jalan keluar dari persoalan ini. Banyak faktor mempengaruhi bentuk partisipasi masyarakat, dimana salah satunya adalah aspek heterogenitas dan karakteristik masyarakatitu sendiri.

Terdapat sejumlah kajian terdahulu tentang faktor heterogenitas yang mempengaruhi bentuk partisipasi masyarakat dalam pengelolaan kawasan hutan dengan fokus dan tujuan yang beragam. (Gibson \& Koontz 1998; Varughese. 1999, 2000; Gibson 2000; Gibson \& Becker 2000; Varughese \& Ostrom 2001) dalam Poteete and Elinor 2004, membuktikan bahwa heterogenitas berpengaruh pada bentuk pengelolaan dan ketertarikan masyarakat dalam pengelolaan hutan. Selain itu, terdapat pula kajian yang mempertanyakan perihal kemampuan masyarakat lokal dalam mengelola dan mempertahankan kelestarian sumberdaya alam, diantaranya Maertens et al. (2002) dan Sitorus (2004) dalam Golar (2007).
Kajian-kajian tersebut di atas telah menjelaskan tentang partisipasi dengan berbagai faktor yang mempengaruhi aktivitas keterlibatan masyarakat. Namun demikian, kajian-kajian tersebut belum mampu menjelaskan bagaimana peran partisipasi masyarakat, heterogenitas serta karakteristik individu dan organisasi terhadap efektivitas pencapaian partisipasi masyarakat dalam pengelolaan kawasan tersebut.

Dari uraian di atas, maka permasalahan yang dikaji dirumuskan sebagai berikut:

(1) Bagaimana peran partisipasi masyarakat dalam pengelolaan kawasan HLGN?

(2) Mengetahui heterogenitas dan karakteristik individu serta organisasi yang mempengaruhi partisipasi masyarakat dalam mengelola sumberdaya HLGN?

Penelitian ini bertujuan untuk mengetahui dan mengukur partisipasi masyarakat dalam pengelolaan kawasan Hutan Lindung dan menganalisis heterogenitas dan karakteristik individu dan organisasi masyarakat yang mempengaruhi tingkat partisipasi dalam pengelolaan kawasan Hutan Lindung.

\section{METODE PENELITIAN}

\section{A. Desain Penelitian}

Penelitian ini merupakan suatu penelitian survei yang bersifat deskriptif korelasional. Variabel tidak bebas dalam penelitian adalah partisipasi masyarakat dalam kegiatan perencanaan, pelaksanaan, penerimaan manfaat serta monitoring dan evaluasi terhadap kawasan hutan lindung sedangkan variabel bebasnya terdiri dari kelompok variabel faktor individu dan faktor organisasi yang merupakan karakteristik masyarakat. Faktor individu terdiri dari variabel: (1) pengetahuan tentang hutan lindung, (2) luas penguasaan lahan hutan, (3) status pemilikan lahan hutan, (4) pendapatan dari pengusahaan dusun, (5) nilai aset, (6) identitas daerah asal responden, (7) tingkat pendidikan, (8) umur, (9) jumlah tanggungan dan (10) lama keterlibatan dalam organisasi. Faktor organisasi terdiri dari variabel: (1) persepsi tentang organisasi (komunikasi dan informasi, pemahaman aturan organisasi, pengambilan keputusan, penyelesaian masalah) dan (2) hubungan pengurus dan anggota organisasi. 


\section{B. Populasi dan Sampel}

Populasi penelitian ini adalah kelompok masyarakat yang aktif dalam pengelolaan lahan (dusung) di sekitar kawasan Hutan Lindung Gunung Nona Kota Ambon dan berbagai pihak yang terlibat dalam pengelolaan kawasan yang akan diidentifikasi dengan cara analisis stakeholder. Unit analisis penelitian adalah individu yaitu masyarakat pengelola dusung untuk memahami faktor-faktor yang mempengaruhi tingkat partisipasi mereka dalam kegiatan pengelolaan kawasan. Jumlah sampel masyarakat pada setiap desa sampel adalah sebanyak 30 orang untuk tiap desa yang mana didasari pada jumlah pemilik dusung pada tiap desa yakni \pm 50 orang, pemilihan sampel dilakukan secara sengaja (purposive sampling).

\section{Lokasi dan Waktu Penelitian}

Penelitian ini dilakukan pada kawasan Hutan Lindung Gunung Nona di Kota Ambon, Provinsi Maluku mulai dari bulan Oktober sampai dengan bulan Desember 2010.

\section{Pengumpulan Data}

Dalam penelitian ini, pengumpulan data dilakukan dengan cara wawancara dan pengisian kuesioner. Wawancara dilakukan khusus bagi pemilik dusung dan dilengkapi dengan kuisioner yang mengambarkan karakteristik dan keterlibatannya dalam berorganisasi.

\section{E. Analisis Data}

DUntuk menggambarkan hubungan antara karakteristik responden (heterogenitas) dan tingkat partisipasinya digunakan analisis distribusi frekuensi dengan tabulasi silang yang kemudian di uji dengan teknik Chi kuadrat (Chi Square) dengan rumus sebagai berikut (Djarwanto dan Sudjana 1996) dalam Sugiyono,2007:

$$
\begin{aligned}
& \mathrm{X}^{2}=\left(\mathrm{f}_{\mathrm{o}}-\mathrm{f}_{\mathrm{h}}\right)^{2} \text { dimana }: \mathrm{X}^{2}=\text { uji Chi kuadrat } \\
& \text { fo = nilai yang diamati (nilai } \\
& \text { observasi) } \\
& \mathrm{fh}=\text { nilai yang diharapkan } \\
& \text { (nilai harapan) }
\end{aligned}
$$

Pengujian signifikansi antara tingkat partisipasi dengan faktor heterogenitas dilakukan dengan membandingkan nilai $\mathrm{X}^{2}$ hitung dengan $\mathrm{X}^{2}$ tabel dengan kriteria sebagai berikut:

a. Jika $\mathrm{X}^{2}$ hitung $>\mathrm{X}^{2}$ tabel berarti variabel heterogenitas mempunyai hubungan dengan tingkat partisipasinya.

b. Jika $\mathrm{X}^{2}$ hitung $<\mathrm{X}^{2}$ tabel berarti variabel heterogenitas tidak mempunyai hubungan dengan tingkat partisipasinya.

Untuk mengetahui derajat keeratan hubungan antara variabel bebas (heterogenitas) dengan variabel terikat (tingkat partisipasi) maka digunakan uji koefisien kontingensi dengan rumus Sudjana (1996):

$$
\begin{aligned}
& \mathrm{x}^{2} \\
& C=------- \text { dimana }: C=\text { koefisien kontingensi } \\
& \mathrm{x}^{2}+\mathrm{n} \quad \mathrm{x}^{2}=\text { nilai } \mathrm{x}^{2} \text { hitung } \\
& \mathrm{n}=\text { jumlah responden }
\end{aligned}
$$

Nilai C berkisar antara 0-1,00 makin besar nilai $C$ berarti hubungan antara 2 (dua) variabel makin erat. Pedoman untuk memberikan interpretasi koefisien kontigensi digunakan batasan yang dikemukan oleh Sugiyono (2007) seperti disajikan pada Tabel 1.

Tabel 1.Nilai interpretasi koefisien korelasi dan tingkat hubungan

Table 1. Value of correlation coefficients and level of relationship

\begin{tabular}{|c|c|}
\hline $\begin{array}{c}\text { Interval koefisien } \\
\text { Coefficient interval }\end{array}$ & $\begin{array}{c}\text { Tingkat hubungan } \\
\text { Relationship level }\end{array}$ \\
\hline $0,00-0,199$ & Sangat rendah \\
\hline $0,20-0,399$ & Rendah \\
\hline $0,40-0,599$ & Sedang \\
\hline $0,60-0,799$ & Kuat \\
\hline $0,80-1.00$ & Sangat kuat \\
\hline
\end{tabular}

Sumber (Source) : Sugiyono, 2007 


\section{HASIL DAN PEMBAHASAN}

\section{A. Karakteristik Individu}

Karakteristik individu sebagai kelompok variabel bebas dalam penelitian ini terdiri dari: (1) pengetahuan tentang HLGN, (2) luas lahan dusung garapan, (3) status pemilikan lahan dusung,
(4) pendapatan per tahun responden, (5) umur responden, (6) lama keterlibatan dalam organisasi masyarakat, (7) pendidikan responden, (8) nilai aset/kekayaan, (9) jumlah tanggungan keluarga dan (10) identitas asal responden. Keragaman setiap variabel tersebut secara deskriptif dipaparkan pada Tabel 2.

Tabel 2. Keragaman karakteristik individu masyarakat pengelola dusung

Table 2. The diversity of individual characteristics of the dusung community organizer

\begin{tabular}{|c|c|c|c|c|}
\hline $\begin{array}{l}\text { Karakteristik individu } \\
\text { Individual characteristics }\end{array}$ & $\begin{array}{c}\text { Desa (Village) } \\
\text { Amahusu }\end{array}$ & $\begin{array}{c}\text { Desa (Village) } \\
\text { Urimesing }\end{array}$ & $\begin{array}{c}\text { Jumlah orang } \\
\text { (Number of } \\
\text { people) }\end{array}$ & $\begin{array}{c}\text { Presentase } \\
\text { (Percentage) } \\
(\%)\end{array}$ \\
\hline
\end{tabular}

Pengetahuan tentang HLGN

Sangat kurang memahami

5

Kurang memahami

Cukup baik memahami

Sangat baik memahami

6

5

14

Luas Penguasaan dusung

a. Penggolongan berdasarkan

standar luas dusung

Dusung luas (2,5-5 ha)

Dusung sedang (1-2,5 ha)

Dusung sempit $(<1 \mathrm{ha})$

b. Penggolongan berdasarkan

kelompok responden

Dusung sempit (<1 ha)

Dusung luas (1 - 5 ha)

Status Pemilikan lahan dusung

Dusung adat

Dusung milik sendiri dengan

sertifikat

Dusung disewa.

Tanpa status

Pandapatan

rendah (1 - 5 juta)

tinggi (5- 10 juta)

Umur

Muda (30-45)

Tua (47-72)

Keterlibatan dalam organisasi

Keanggotaan baru (1-4 thn)

Keanggotaan lama (4-6 thn)

Tingkat pendidikan

SD

SMP

SMU

Univ/akademi
0

\begin{tabular}{|c|c|c|}
\hline 7 & 12 & 20 \\
\hline 5 & 17 & 28.33 \\
\hline 18 & 31 & 51.67 \\
\hline 18 & 31 & 51.67 \\
\hline 12 & 29 & 48.33 \\
\hline 9 & 20 & 33.33 \\
\hline 5 & 7 & 11.67 \\
\hline 0 & 0 & 0.00 \\
\hline 16 & 32 & 53.33 \\
\hline 14 & 26 & 43.33 \\
\hline 16 & 34 & 56.67 \\
\hline 5 & 8 & 13.33 \\
\hline 25 & 52 & 86.67 \\
\hline 2 & 5 & 8.33 \\
\hline 28 & 55 & 91.67 \\
\hline 4 & 8 & 13.33 \\
\hline 9 & 17 & 28.33 \\
\hline 16 & 34 & 56.67 \\
\hline 1 & 1 & 1.67 \\
\hline
\end{tabular}


Tabel 2.Lanjutan

Table 2. Continued

\begin{tabular}{|c|c|c|c|c|}
\hline $\begin{array}{l}\text { Karakteristik Individu } \\
\text { Individual characteristics }\end{array}$ & $\begin{array}{c}\text { Desa (Village) } \\
\text { Amahusu }\end{array}$ & $\begin{array}{c}\text { Desa (Village) } \\
\text { Urimesing }\end{array}$ & $\begin{array}{c}\text { Jumlah orang } \\
\text { (Number of } \\
\text { people) }\end{array}$ & $\begin{array}{c}\text { Presentase } \\
\text { (Percentage) } \\
(\%)\end{array}$ \\
\hline \multicolumn{5}{|l|}{ Nilai asset } \\
\hline $5-10 \mathrm{jt}$ & 13 & 11 & 24 & 40.00 \\
\hline $10-20 \mathrm{jt}$ & 10 & 15 & 25 & 41.67 \\
\hline$>20 \mathrm{jt}$ & 7 & 4 & 11 & 18.33 \\
\hline \multicolumn{5}{|l|}{ Jumlah tanggungan } \\
\hline $1-4$ org & 8 & 5 & 13 & 21.67 \\
\hline $5-8$ org & 22 & 23 & 45 & 75.00 \\
\hline$>8$ org & 0 & 2 & 2 & 3.33 \\
\hline \multicolumn{5}{|l|}{ Identitas asal } \\
\hline Masyarakat Asli & 28 & 28 & 56 & 93.33 \\
\hline Pendatang (telah menetap lama) & 1 & 2 & 3 & 5.00 \\
\hline Pengungsi (menetap karena konflik) & 1 & 0 & 1 & 1.67 \\
\hline
\end{tabular}

\section{B. Karakteristik Organisasi}

Variabel yang dikelompokkan ke dalam kelompok variabel karakteristik organisasi terdiri dari : (1) presepsi tentang organisasi yang meliputi komunikasi dan informasi, pemahaman aturan organisasi, pengambilan keputusan, penyelesaian masalah, (2) hubungan pengurus dengan anggota. Keragaan setiap variabel tersebut tertera pada Tabel 3.

(1) Komunikasi dan informasi dimana melalui penelitian ini tergambar bahwa 46 orang atau 76,67 $\%$ responden menyatakan bahwa jalinan komunikasi dan informasi mereka dalam berorganisasi dikategorikan baik. Hal inipun tercermin pada pola komunikasi yang dibangun didalam masyarakat dimana hingga saat ini pada desa Urimesing masih memanfaatkan fungsi Marinyo (salah satu perangkat desa adat) yaitu pesuruh desa/negeri yang bertugas menyampaikan perintah dan pemberitahuan dari pemerintah kepada masyarakat Urimesing dengan istilah "bataria tita" atau tabaos (membacakan pengumuman di hadapan masyarakat). Di sini tergambar bahwa adanya sistem informasi yang terbuka yang akan menjadi kontrol masyarakat terhadap penyimpangan-penyimpangan kebijakan maupun pengelolaan hutan di lapangan yang senantiasa dapat terjadi.

(2) Pemahaman aturan organisasi, melalui penelitian ini tergambar 35\% responden sangat dan cukup paham memahami aturan organisasi yang ia jalani. Saat ini, dalam penerapan salah satu kebijakan Pemerintah yang berhubungan dengan pengelolaan kawasan, telah dimulai pemberlakuan sistem insentif bagi masyarakat yang terlibat dalam kelompok pemeliharaan tanaman reboisasi pada lokasi HLGN. Kelompok ini telah menjalankan fungsi selama setahun dan senantiasa di evaluasi peranannya oleh Pemerintah.

(3) Pengambilan keputusan, melalui penelitian ini tergambar $76,67 \%$ responden memberikan penilaian "baik" tiap proses dan keputusan yang diambil dalam aktivitas berorganisasi selama ini. Saat ini bagi masyarakat kedua desa, pengambilan keputusan diambil melalui pertemuan bersama yang melibatkan semua pihak terkait. Sebagai contoh keterlibatan masyarakat dalam aktivitas reboisasi HLGN dimana keikutsertaan masyarakat secara berkelompok dan penentuan lokasi pemeliharaan tanaman reboisasi ditentukan berdasarkan pertemuan bersama semua pihak.

(4) Penyelesaian masalah, melalui penelitian ini tergambar $41,67 \%$ responden memberikan penilaian cukup baik terhadap upaya penyelesaian berbagai masalah di dalam berorganisasi di masyarakat. Upaya penyelesaian masalah selama ini diberlakukan secara bertahap dimana dimulai dengan pelaporan dan penyelesaian yang diupayakan oleh kepala dusun atau ketua RT, apabila tidak terselesaikan di lanjutkan ke tingkat desa/negeri dan lebih lanjut diupayakan ke tingkat pengadilan. Untuk persoalan dusung, upaya penyelesaian diupayakan terlebih dahulu oleh 
Tabel 3. Keragaman karakteristik organisasi masyarakat pengelola dusun

Table 3. Characteristics variation in community organization managing dusung

\begin{tabular}{|c|c|c|c|c|}
\hline $\begin{array}{l}\text { Karakteristik organisasi } \\
\text { Organization characteristic }\end{array}$ & $\begin{array}{c}\text { Desa (Village) } \\
\text { Amahusu }\end{array}$ & $\begin{array}{c}\text { Desa (Village) } \\
\text { Urimesing }\end{array}$ & $\begin{array}{l}\text { Jumlah orang } \\
\text { Total people }\end{array}$ & $\begin{array}{c}\text { Presentase (Percentage) } \\
(\%)\end{array}$ \\
\hline \multicolumn{5}{|l|}{ Presepsi tentang organisasi } \\
\hline kurang baik & 0 & 0 & 0 & 0.00 \\
\hline cukup baik & 0 & 8 & 8 & 13.33 \\
\hline baik & 24 & 22 & 46 & 76.67 \\
\hline sangat baik & 0 & 0 & 0 & 0.00 \\
\hline \multicolumn{5}{|l|}{ b.Pemahaman aturan organisasi } \\
\hline tidak paham & 0 & 2 & 2 & 3.33 \\
\hline sedikit paham & 1 & 7 & 8 & 13.33 \\
\hline cukup paham & 10 & 11 & 21 & 35.00 \\
\hline sangat paham & 11 & 10 & 21 & 35.00 \\
\hline \multicolumn{5}{|l|}{ c. Pengambilan keputusan } \\
\hline kurang baik & 0 & 2 & 2 & 3.33 \\
\hline cukup baik & 0 & 1 & 1 & 1.67 \\
\hline Baik & 20 & 26 & 46 & 76.67 \\
\hline sangat baik & 4 & 1 & 5 & 8.33 \\
\hline \multicolumn{5}{|l|}{ d.Penyelesaian masalah } \\
\hline kurang baik & 0 & 0 & 0 & 0.00 \\
\hline cukup baik & 16 & 9 & 25 & 41.67 \\
\hline Baik & 2 & 21 & 23 & 38.33 \\
\hline \multicolumn{5}{|l|}{$\begin{array}{l}\text { Hubungan pengurus dengan } \\
\text { anggota }\end{array}$} \\
\hline kurang baik & 0 & 7 & 7 & 11.67 \\
\hline cukup baik & 11 & 4 & 15 & 25.00 \\
\hline Baik & 12 & 14 & 26 & 43.33 \\
\hline
\end{tabular}

kedua pihak yang bertikai dan difasilitasi oleh kewang.

Dari hasil penelitian ini menilai bahwa hubungan pengurus dan anggota di dalam berorganisasi selama ini dikategorikan baik (43,33\%) dan kurang baik $(11,67 \%)$. Hal ini menggambarkan bahwa telah terjadi kesesuaian hubungan sebagaimana yang diharapkan oleh anggota masyarakat. Kawasan HLGN adalah sumberdaya yang dikuasai oleh kelompok masyarakat tertentu yaitu sumberdaya yang dikuasai dan dikelola berdasarkan tata aturan kelompok masyarakat tersebut. Hal ini nampak pada sistem pengelolaan dusung yang berlaku dimana akses tiap individu anggota kelompok terhadap sumberdaya yang dikuasai bersama menghasilkan pendapatan yang cukup nyata. Seringkali tambahan manfaat ini tidak menguntungkan apabila harus disediakan oleh individu pengelola dusung secara sendiri-sendiri (Kartodihardjo, 2006) untuk itulah diperlukan partisipasi yang dikoordinasi oleh pengurus organisasi di masyarakat, misalnya untuk memanen hasil cengkeh dari pemilik dusung yang memiliki luas dusung yang besar, ia membutuhkan partisipasi masyarakat yang lain untuk membantunya.

\section{Partisipasi Responden}

Variabel tidak bebas penelitian ini adalah partisipasi masyarakat di sekitar kawasan hutan lindung. Adapun hasilnya tercantum pada Tabel 4 berikut ini: 
Tabel 4. Partisipasi responden dalam pengelolaan Hutan Lindung

Table 4. Respondents' participation in the management of Protected Forest

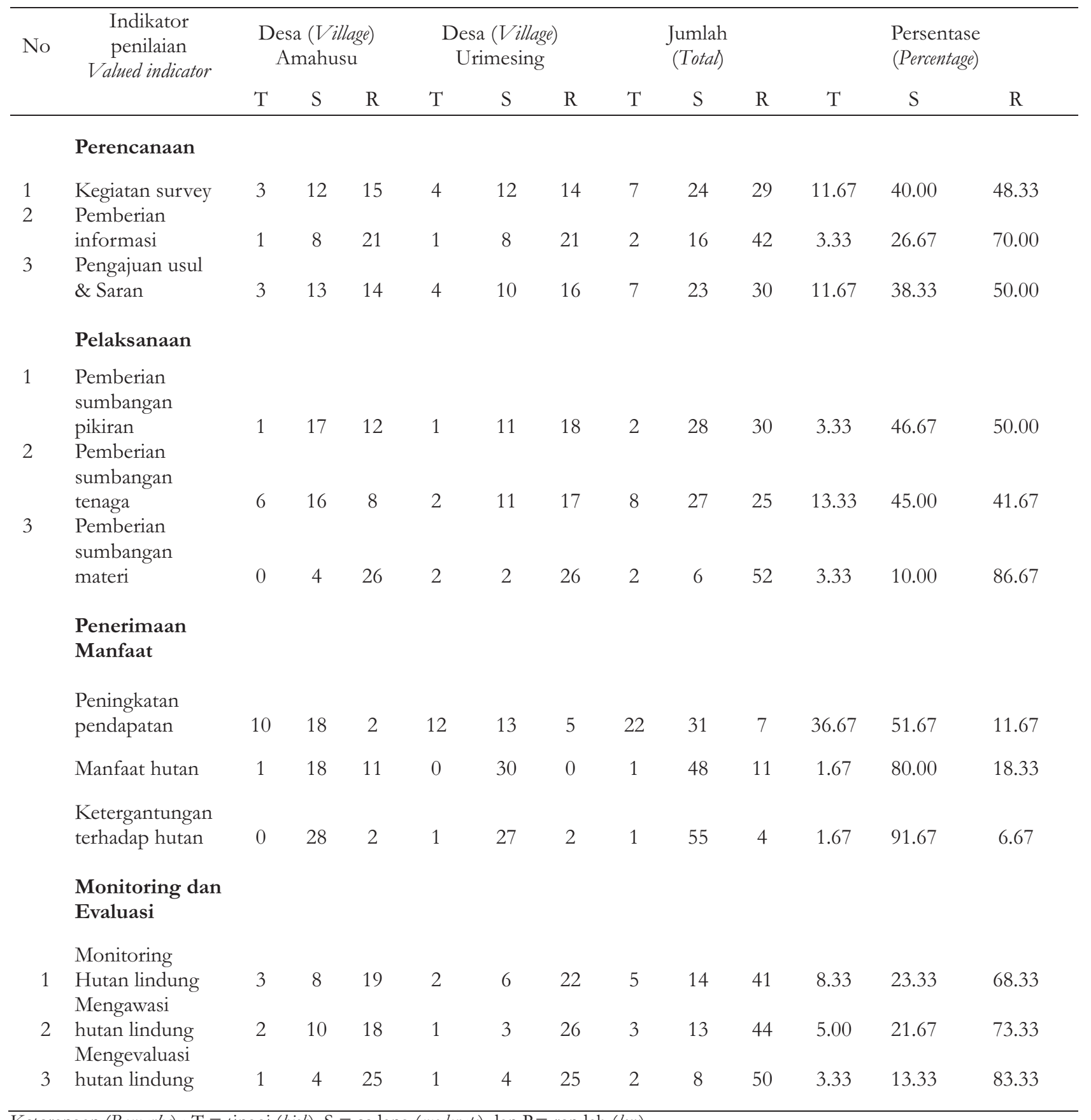

Keterangan (Remarks) $: \mathrm{T}=$ tinggi (high), $\mathrm{S}=$ sedang (moderate) dan $\mathrm{R}=$ rendah (low)

Adapun yang dimaksudkan dengan partisipasi tinggi pada masing- masing indikator penilaian adalah apabila responden ikut serta aktif dalam keseluruhan tiap kegiatan tersebut secara aktif (Perencanaan hingga monitoring dan evaluasi dari kegiatan tersebut), sedangkan partisipasi sedang apabila responden hanya terlibat pada 2 atau 3 proses secara aktif (hanya pada tahap perencanaan dan pelaksanaan saja dari kegiatan itu) dan partisipasi rendah adalah apabila responden hanya aktif pada 1 tahapan proses (misalnya pada perencanaan dari kegiatan tersebut).

1. Partisipasi masyarakat dalam perencanaan

Dari tabel tersebut menunjukan bahwa masyarakat sekitarnya belum dilibatkan untuk melakukan kegiatan perencanaan terhadap pelestarian hutan lindung. Untuk kegiatan survei, hanya 7 responden atau $11,67 \%$ yang 
pernah melakukan bersama dengan petugas dari Dinas Pertanian dan Kehutanan Kota Ambon. Masyarakat yang aktif memberikan informasi kepada petugas untuk pengelolaan kawasan hanya 2 responden atau 3,33\% dan yang pernah mengajukan usul, saran atau pendapat hanya sebesar 7 responden atau $11,67 \%$.

2. Partisipasi Masyarakat dalam Pelaksanaan

Dari tabel di atas menunjukan bahwa masyarakat setempat dalam memberikan sumbangan saran masih rendah dan hanya beberapa anggota masyarakat yang memberikan sumbangan pikiran, tenaga maupun materi untuk pengelolaan HLGN yaitu sebesar 3,33\% untuk sumbangan pikiran, untuk sumbangan tenaga 13,33\% dan sumbangan materi sebesar 3,33\%.

3. Partisipasi Masyarakat dalam Penerimaan Manfaat

Dari tabel di atas menunjukkan bahwa masyarakat berpartisipasi tinggi tethadap pengelolaan kawasan HLGN apabila ada motivasi untuk keuntungan mereka yaitu peningkatan pendapatannya yaitu sebesar 36,67\%. Tetapi mereka mengabaikan manfaat hutan terhadap kelestarian lingkungan terutama dapat mencegah erosi dan tanah longsor serta sumber air bersih. Ketergantungan hidup terhadap hutan rendah sebesar 1,67\%, hal ini karena mereka juga mengusahakan dusung di dalam kawasan hutan.

4. Partisipasi Masyarakat dalam Monitoring dan Evaluasi

Dari tabel tersebut menunjukkan bahwa masyarakat setempat masih rendah tingkat partisipasinya terhadap kegiatan monitoring, mengawasi dan mengevaluasi hutan lindung yaitu sebesar $8,33 \%, 5 \%$ dan $3,33 \%$.

\section{Hubungan antara Karakteristik Responden dengan Partisipasi Masyarakat dalam Kegiatan Pengelolaan HLGN}

Hubungan karakteristik responden dengan partisipasi masyarakat dalam pengelolaan kawasan HLGN dikaji berdasarkan analisis Chi Square $\left(\mathrm{X}^{2}\right)$ dan digunakan uji Koefisien Kontigensi (C). Nilai $\mathrm{X}^{2}$ dan koefisien keeratan hubungan dari masingmasing variabel heterogenitas dari kedua desa dapat dilihat pada Tabel 5 dimana penilaian hubungan didasarkan pada Tabel 1.

Tabel5. Hubungan berbagai karakteristik responden dengan partisipasi, dan tingkat keeratan hubungannya di Desa Amahusu

Table 5. Relationship between various respondent characteristic and participation, and the level of relationship in Amahusu Village)

\begin{tabular}{llccc}
\hline No & \multicolumn{1}{c}{$\begin{array}{c}\text { Karakteristik } \\
\text { (Characteristics) }\end{array}$} & $\begin{array}{c}\text { Nilai X } \\
\left(X^{2} \text { value }\right)\end{array}$ & $\begin{array}{c}\text { Nilai C } \\
(\text { C value })\end{array}$ & $\begin{array}{c}\text { Tingkatan hubungan } \\
(\text { Level of relationshi })\end{array}$ \\
\hline 1 & Umur & 3,600 & 0,327 & Tidak ada \\
2 & Pendidikan & 0,764 & 0,158 & Tidak ada \\
3 & Jumlah tanggungan keluarga & 1,765 & 0,236 & Tidak ada \\
4 & Pengetahuan & 25,378 & 0,677 & Ada hubungan/kuat \\
5 & Luas dusun & 12,573 & 0,543 & Ada hubungan/sedang \\
6 & Status pemilikan & 16,223 & 0,592 & Ada hubungan/sedang \\
7 & Pendapatan & 1,536 & 0,221 & Tidak ada \\
8 & Nilai aset & 9,143 & 0,483 & Tidak ada \\
9 & Lama keterlibatan dalam organisasi & 17,400 & 0,648 & Ada hubungan/kuat \\
10 & Hubungan didalam organisasi & 13,010 & 0,593 & Ada hubungan/sedang \\
11 & Komunikasi dan Informasi & 0 & 0 & Responden menilai baik \\
12 & Pemahaman aturan organisasi & 3,152 & 0,341 & Tidak ada \\
13 & Pangambilan keputusan & 3,000 & 0,333 & Tidak ada \\
14 & Penyelesaian masalah & 9,611 & 0,535 & Ada hubungan/sedang \\
\hline
\end{tabular}

Pada Tabel 5 dan 6 terlihat bahwa karakteristik individu dan organisasi yang mempunyai hubungan erat dan berpengaruh terhadap partisipasi masyarakat dalam pengelolaan kawasan HLGN adalah pengetahuan tentang hutan lindung, luas penguasaan lahan dusung, status pemilikan dusung, lama keterlibatan dalam organisasi serta hubungan pengurus dan anggota masyarakat dalam organisasi. Hal yang sama juga berlaku bagi institusi lokal, seperti harta karun yang potensinya 
Tabel 6. Hubungan berbagai karakteristik dengan partisipasi dan tingkat keeratan hubungannya di Desa Urimesing

Table 6. Relationship between various respondent characteristics and participation, and the level of relationship in Urimesing Village)

\begin{tabular}{llccc}
\hline No & \multicolumn{1}{c}{$\begin{array}{c}\text { Karakteristik } \\
\text { (Characteristics) }\end{array}$} & $\begin{array}{c}\text { Nilai X } \\
\left(X^{2} \text { value }\right)\end{array}$ & $\begin{array}{c}\text { Nilai C } \\
(\text { C value })\end{array}$ & $\begin{array}{c}\text { Tingkatan hubungan } \\
\text { (Level of relationship }\end{array}$ \\
\hline 1 & Umur & 5,250 & 0,386 & Tidak ada \\
2 & Pendidikan & 8,125 & 0,462 & $\begin{array}{c}\text { Tidak ada } \\
\text { Tidak ada }\end{array}$ \\
3 & Jumlah tanggungan keluarga & 2,689 & 0,287 & Ada hubungan/sedang \\
4 & Pengetahuan & 15,910 & 0,589 & Ada hubungan/sedang \\
5 & Luas dusun & 14,820 & 0,575 & Ada hubungan/sedang \\
6 & Status pemilikan & 16,207 & 0,592 & Ada hubungan/sedang \\
7 & Pendapatan & 8,693 & 0,474 & Ada hubungan/kuat \\
8 & Nilai aset & 22,033 & 0,651 & Ada hubungan/sedang \\
9 & Lama Keterlibatan dalam organisasi & 6,562 & 0,424 & Ada hubungan/kuat \\
10 & Hubungan didalam organisasi & 19,890 & 0,631 & Tidak ada \\
11 & Komunikasi dan Informasi & 1,643 & 0,228 & Tidak ada \\
12 & Pemahaman aturan organisasi & 7,710 & 0,452 & Tidak ada \\
13 & Pengambilan keputusan & 4,038 & 0,344 & Tidak ada \\
14 & Penyelesaian masalah & 0,067 & 0,047 & \\
\hline
\end{tabular}

belum termanfaatkan, demikian juga pengetahuan masyarakat. Masyarakat setempat seringkali memiliki pengetahuan yang luas tentang hutan itu sendiri (terutama dusung dengan kawasan hutan di sekitarnya) karena pengalaman pribadi dan pengamatan jangka panjang dan juga pelajaranpelajaran nyata dari orangtua dan nenek moyang mereka. Pengetahuan tersebut tidak selalu nyata dan merata diantara kelompok masyarakat yang hidup pada hutan lindung. Memahami potensi pengetahuan setempat; pemahaman mereka tentang hutan; dari siapa diperolehnya dan mengetahui cara untuk mengaksesnya merupakan tugas penting sebagai katalisator dalam partisipasi. Penyatuan pengetahuan setempat dan luar penting dilakukan. Pertukaran berbagai jenis pengetahuan sangat produktif bagi berbagai pihak yang berkepentingan bagi kawasan HLGN tersebut.

Status pemilikan dusung adalah perorangan dan memiliki fungsi produksi untuk memenuhi kebutuhan keluarga. Masyarakat telah mempertahankan fungsi dusung tersebut dari generasi ke generasi. Status pemilikannya perorangan dan keluarga, di mana ada yang telah disertifikasi dan ada yang tanpa status. Tidak mudah mengatasi persoalan ini, upaya penyelesaian yang diusahakan oleh masyarakat adalah dengan mengeratkan hubungan kekerabatan (antar marga yang diberi hak penguasaan dusun) sehingga dengan demikian ada institusi (berdasarkan hubungan kekerabatan) yang mengatur hak-hak individu, hak-hak bersama dan mengatur fungsinya. Sistem pengelolaan hutan seperti ini bukan hanya mewujudkan orientasi keuntungan individu pengelola, melainkan juga memperhatikan kepentingan bersama dan fungsi kawasan hutan itu sendiri. Luas penguasaan dusung dan status pemilikannya tidak akan menjadi hambatan bagi upaya membangun partisipasi yang ada, justru partisipasi akan membantu mengatur mekanisme institusi lokal tersebut. Institusi lokal membantu mewujudkan keadilan di mana disamping memegang hak, individu memegang tanggungjawab. Hak individu diperoleh dan diakui oleh anggota masyarakat sehingga dipegang secara aman, karena individu juga diberi tanggung jawab untuk kepentingan bersama (menjaga kondisi hutan sekitarnya). Mekanisme keadilan mendorong masyarakat membantu mengamankan dan menuntut keberadaan sumberdaya hutan lindung tersebut tetap terjaga.

Aturan main yang mengatur hubungan antar manusia untuk menghambat munculnya perilaku oportunistik dan saling merugikan (free riding, rent seeking dan asimetrik informasi) selalu berusaha diatasi antar pemilik dusung. Salah satu cara mengatasinya adalah membangun keterlibatan tiap individu dalam berorganisasi dan menciptakan hubungan kerja yang sesuai untuk kepentingan bersama sehingga upaya untuk memaksimumkan kesejahteraan individu lebih dapat diantisipasi. Melalui berorganisasi, upaya membangun koordinasi termasuk pertukaran informasi dan berbagai hal serta efisiensi biaya dapat diatasi. Hal ini sejalan dengan yang dikemukan oleh Agrawal 
dan Gibson (1999) bahwa lebih seringnya interaksiinteraksi dapat menurunkan biaya-biaya untuk bagaimana membuat keputusan-keputusan yang kolektif tersebut. Untuk itulah maka partisipasi memberikan pilihan untuk aspirasi tiap individu dan sangat mempengaruhi kebijakan yang dibuat.

Arnstein (1995) menyatakan bahwa tingkat partisipasi sangat bervariasi mulai tahap manipulasi, terapi, menginformasikan, konsultasi, menentramkan (placation), kemitraan, delegasi kekuasaan hingga kontrol masyarakat. Tingkatan tersebut dikenal dengan istilah tangga partisipasi. Tangga partisipasi ini akan sangat membantu mempelajari sejauhmana tingkat peran partisipasi yang dimainkan oleh masyarakat dan bagaimana membuatnya lebih baik. Untuk tangga partisipasi yang terlihat pada bentuk peran serta masyarakat dalam pengelolaan kawasan HLGN telah berada pada tangga menginformasikan dan tangga kemitraan dimana masyarakat disosialisasikan dan diinformasikan tentang fungsi dan manfaat kawasan HLGN dengan harapan mereka memahami dan berpartisipasi menjaga kelestarian kawasan dan sebagai mitra kerja dalam pengelolaan kawasan ini. Tingkatan partisipasi ini belum optimal seperti yang diharapkan karena upaya menginformasikan lebih dikhususkan pada pemimpin mereka begitu pula keikutsertaan sebagai mitra kerja hanya pada proyek penanaman dan pemeliharaan tanaman reboisasi.

Kawasan HLGN yang sangat dekat dengan kota Ambon secara tidak langsung mengakibatkan kawasan ini mengalami tekanan sebagai implikasi dari terganggunya kinerja tersebut. Gambaran terjadinya degradasi terhadap sumberdaya yang ada mengakibatkan fungsi hidrologi HLGN terganggu. Upaya mengatasinya dilakukan oleh pemerintah kota Ambon khususnya dinas kehutanan dengan memfungsikan kembali kewang (sebutan bagi polisi hutan di Maluku) pada masing-masing dusung.

Masyarakat kedua desa memiliki homogenitas pada aspek budaya (adat Maluku) dan minat ekonomi (sistem pengelolaan dusungnya), hal ini memudahkan menjalankan partisipasi dan meningkatkan partisipasi masyarakat dalam pengelolaan kawasan HLGN.

\section{KESIMPULAN DAN SARAN}

\section{A. Kesimpulan}

1. Partisipasi masyarakat dalam kegiatan perencanaan, pelaksanaan, penerimaan manfaat serta evaluasi dan monitoring terhadap kawasan HLGN masih tergolong rendah.

2. Faktor karakteristik individu dan organisasi yang mempunyai hubungan erat dan berpengaruh terhadap partisipasi masyarakat dalam pengelolaan kawasan HLGN adalah pengetahuan tentang hutan lindung, luas penguasaan lahan dusung, status pemilikan dusung, lama keterlibatan dalam organisasi serta hubungan pengurus dan anggota masyarakat dalam organisasi.

3. Masyarakat menampakkan partisipasi kalkulatif dalam peran mereka sebagai pengelola HLGN dan menampakkan partisipasi dengan ciri kepatuhan moral dalam peran mereka sebagai penggelola dusung.

\section{B. Saran}

1. Faktor penting dari karakateristik Individu dan organisasi yang berpengaruh dan mempunyai hubungan erat terhadap partisipasi adalah Pengetahuan, untuk itu penting dilakukan Penyuluhan atau Pemahaman konsep tentang pentingnya peran hutan lindung bagi berbagai stakeholderyang berperan didalamnya.

2. Perlu diciptakan partisipasi dan mata rantai aksi bersama berbagai stakeholder sehingga kelebihan dan kelemahan dari tiap peran yang dimainkan oleh tiap stakeholder dapat saling melengkapi demi kelestarian HLGN dan kesejahteraan bersama.

\section{DAFTAR PUSTAKA}

Agrawal Arun, Gibson Clark. 1999. Enchantment dan Disenchantment : The role of communi-ty in natural resource conservation. World Development Vol.27,No.4, pp 629-649.Elservier Science.Ltd 
Colfer J Pierce Carol. 2000. Aturan-aturan sederhana Katalisasi Aksi Kolektif dalam Pengelolaan Sumberdaya Alam. CIFOR.

Gibson, C. \& T. Koontz.1998.'When community is not enough: Communities and forests in Southern Indiana" Human Ecology 26: pp $621-647$.

Gibson, C. And C.D. Becker. 2000. People and Forests: Community, institutions, and governance. MIT Press, Cambridge, Massachusetts, USA.

Gibson, C., McKeen, M., \& Ostrom, E. (Eds).2000. People and Forests: Communities institutions and the governance. Cambridge; MIT Press.

Golar. 2007. Strategi adaptasi masyarakat adat Toro. Kajian kelembagaan lokal dalam pengelolaan dan pemanfaatan sumberdaya hutan di Taman Nasional Lore Lindu Propinsi Sulawesi Tengah. Ringkasan Disertasi IPB.

Komite Multistakeholder Forestry Programme, Yayasan WWF-Indonesia. 2006. Kemitraan dalam Pengelolaan Taman Nasional : Pelajaran untuk transformasi kebijakan.

Kartodihardjo, H. 2006. Ekonomi dan Institusi Pengelolaan Hutan. Telaah lanjut analisis kebijakan usaha kehutanan. IDEALS. Gedung Alumni IPB Lantai 2. Bogor

MacKinnon, JK,G. Child, J. Thorsell. 1990. Pengelolaan Kawasan yang Dilindungi di Daerah tropika. Gadjah Mada University Press. Yogyakarta.

Poteete, A. E. Ostrom. 2004. Heterogeneity, Group Size dan Colective Action : The Role of Institutions in Forest Management, Ford Foundation and National Science.

Sugiyono. 2007. Statistika untuk Penelitian. Penerbit Alfabeta Bandung.

Varughese, G.1999. Vollagers, bureaucrats, and forests in Nepal : Designing governance for complex resource. Ph.D. thesis; Workshop in Political Theory and Policy Analysis, Indiana University, Bloomington. IN.USA.

Varughese, G.2000. Population and forest dynamics in the hills of Nepal : Institutional remedies by rural communities. In : People and Forests: Communities, Institutions, and Governance, ed. C. Gibson, M. McKean \& E. Ostrom, pp 193 226. Cambridge, MA. USA: MIT Press.

Varughese, G. E. Ostrom. 2001. The contested role of heterogeneity in collective action: Some evidence from community forestry in Nepal. World Development Vol.29, No. 5,pp 747765 .

Wiratno,D. Indriyo, A.Syarifudin dan A. Kartikasari. 2004. Berkaca di cermin retak. Refleksi konservasi dan Implikasi bagi Pengelolaan Taman Nasional. FORest Press, The Gibbon Foundation Indonesia, Departemen Kehutanan, PILI-NGO Movement.

Yudilastiantoro, C. 2005. Partisipasi masyarakat terhadap pengelolaan hutan lindung di Das Palu (Hulu), Sulawesi Tengah. Info sosial Ekonomi, Pusat Penelitian dan Pengembangan Sosial ekonomi dan Kebijakan Kehutanan. Bogor 